\title{
Carbon credit and emission trading: Anaerobic wastewater treatment
}

\author{
K.Y. Show ${ }^{a}$, D.J. Lee ${ }^{\text {b,* }}$ \\ ${ }^{a}$ Faculty of Science, Engineering \& Technology, University Tunku Abdul Rahman, Jalan University, Bandar Barat, 31900 Kampar, Perak, Malaysia \\ ${ }^{\mathrm{b}}$ Department of Chemical Engineering, National Taiwan University, Taipei 106, Taiwan \\ Received 24 May 2008; accepted 28 May 2008
}

\begin{abstract}
The concept of carbon credit arose out of increasing awareness of the need to reduce emissions of greenhouse gases to combat global warming which was formalized in the Kyoto Protocol. In addition to contribution to sustainable development with energy recovery in the form of methane, carbon credits can be claimed by application of advanced anaerobic processes in wastewater treatment for reducing emissions of greenhouse gases. As anaerobic granular systems are capable of handling high organic loadings concomitant with high strength wastewater and short hydraulic retention time, they could render much more carbon credits than other conventional anaerobic systems. Granular anaerobic processes have become an attractive choice of treatment technology especially for high strength wastewaters, considering the fact that in addition to efficient waste degradation, the carbon credits can be used to generate revenue and to finance the project. This paper presents a scenario on emission reduction based on a methane recovery and utilisation project. An example analysis on emission reduction and the future trend is also outlined.
\end{abstract}

(C) 2008 Taiwan Institute of Chemical Engineers. Published by Elsevier B.V. All rights reserved.

Keywords: Anaerobic granulation; Carbon credit; Certified emission reductions; Clean development mechanism; Methane

\section{Introduction}

Global warming arising from unprecedented emissions of greenhouse gases presents the greatest test humans have ever faced. Increasing global concerns over diminishing crude oil reserve and greenhouse gas emission through combustion of fossil fuels have called for a need for alternative fuels. Use of anaerobic processes for biofuel energy clearly fit this need. Anaerobic granular systems are designed in wastewater treatment to maximize methane yield that would otherwise be fugitive which can either be used for energy or just be flared off. The methane, a greenhouse gas, can be effectively reduced rendering great potential for the Clean Development Mechanism (CDM) initiatives under Kyoto Protocol. In a CDM program, 'carbon credit' represents the amount of reduction of greenhouse gas emissions from an emission source. Carbon credits can be claimed by issuing Certified Emission Reductions (CERs) through advanced anaerobic wastewater treatment. In order to improve treatment efficiency and to claim carbon credits, existing aerobic and low-rate anaerobic

\footnotetext{
* Corresponding author.

E-mail addresses: kyshow2003@yahoo.com.sg (K.Y. Show), djlee@ntu.edu.tw (D.J. Lee).
}

treatment such as those open pond systems can be upgraded to anaerobic granular-sludge systems.

Most chemical processes emit greenhouse gases (Chang et al., 2007; Chen et al., 2007; Chiou et al., 2006; Ghoneim and Aboul-Gheit, 2007; Hacifazlioglu and Sutcu, 2007; He et al., 2007; Hung and Rei, 2007; Kasim et al., 2007; Kim et al., 2006; Li and Teng, 2007; Lin and Shih, 2006, 2007; Ma et al., 2007; Matsuda et al., 2006; Monyanon et al., 2007; Otawara and Kitamura, 2006; Sutcu, 2007; Wang and Chen, 2007; Wang and Liu, 2007a, 2007b; Wang et al., 2007; Wei et al., 2007; Wu and You, 2007; Wu et al., 2006; Yao et al., 2007; Yeh, 2007; Yu et al., 2007a,b,c). A scenario on emission reduction based on a methane recovery and utilisation from a granular-sludge-based anaerobic treatment system is discussed in this paper. An example analysis on emission reductions based on the methane avoidance project is illustrated.

\section{Emission trading}

Emission trading is a regulatory program that allows firms the flexibility to select cost-effective solutions to achieve established environmental goals, which are required to reduce worldwide greenhouse gas emissions to below 1990 levels. Solutions can be achieved by reducing emissions from a 


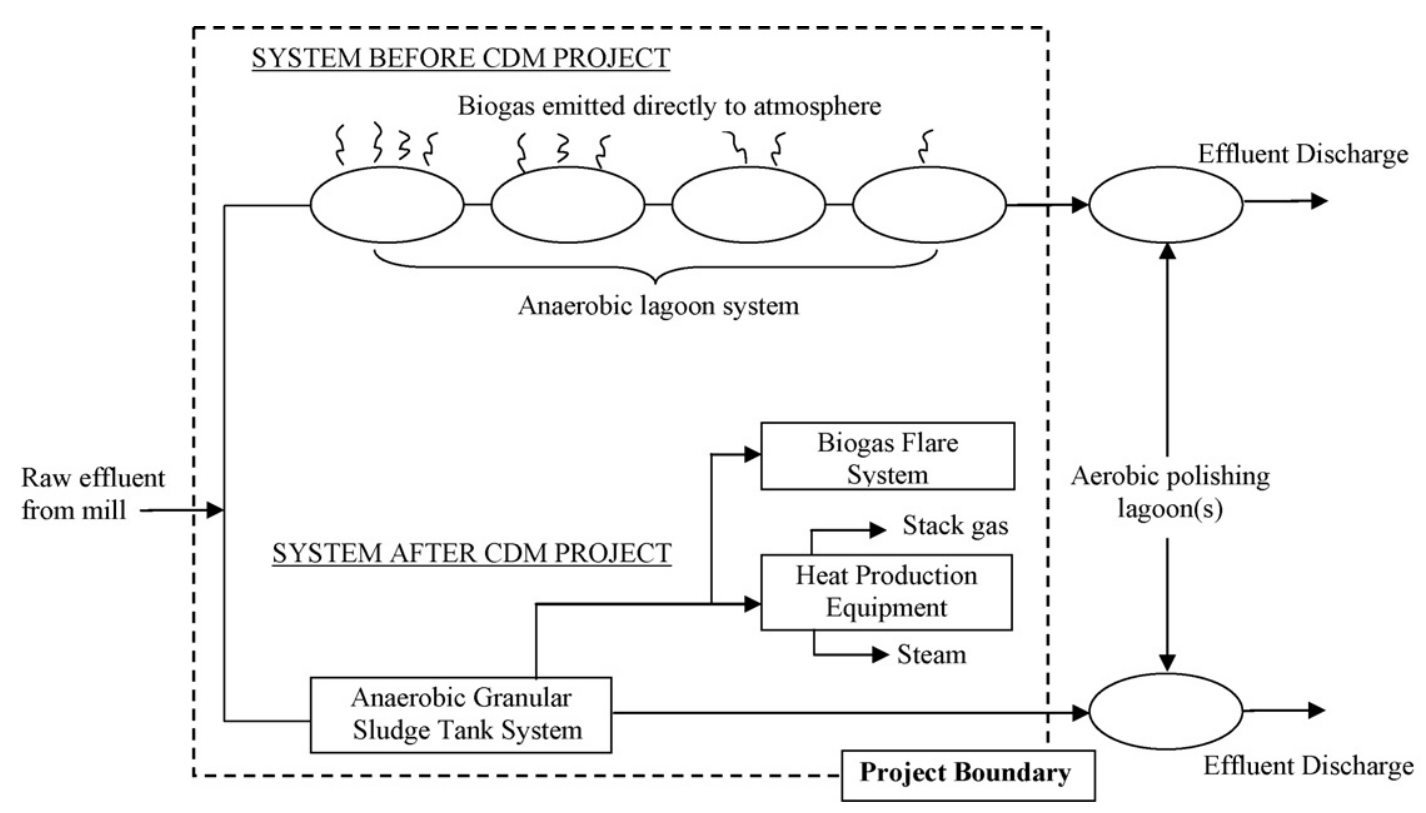

Fig. 1. Layout of the systems before and after the CDM project.

discrete emission unit, by reducing emissions from another place within facility, and/or by purchase emission reductions from another facility. International treaties such as the Kyoto Protocol set quotas on the amount of the greenhouse gases countries can produce over the commitment period from 2008 to 2012. Countries, in turn, set quotas on the emissions of businesses. Emissions trading, as set out by the Kyoto Protocol, allows countries that have emission units to spare, namely emissions permitted to them but not used, may "bank" them for use later, or may sell them to countries that are over their quotas. Thus, a new commodity was produced in the form of CERs or removals. Since carbon dioxide and methane are the principal greenhouse gases, emissions trading are simply of trading in carbon. For trading purposes, one credit is considered equivalent to 1 tonne of carbon dioxide emissions. Carbon is now tracked and traded like any other commodity. In the "carbon market", CERs can be exchanged between businesses or bought and sold in international markets at the prevailing market prices.

It is also possible for developed countries within the trading scheme to sponsor carbon projects that provide a reduction in greenhouse gas emissions in other countries, as a way of generating CERs which can be applied to meeting their own emission targets. The Kyoto Protocol allows this through CDM and Joint Implementation projects, in order to provide flexible mechanisms to aid regulated entities in meeting their compliance with their caps. The recipient countries benefit from advanced technology transfer that allows their factories or plants to operate more efficiently, and hence at lower costs and higher profits. The atmosphere benefits because future emissions are lower than they would have been otherwise. The CDM will be overseen by an Executive Board that has already been established and has approved a series of methodologies for large-scale and smallscale projects.
Most wastewater effluent methane avoidance projects have activities that both reduce anthropogenic greenhouse gas emissions by sources and directly emit less than 60,000 tonnes carbon dioxide equivalent per year, and thus are eligible for small-scale CDM projects. An emission analysis based on project activity involving the installation of a granular anaerobic system for the treatment of palm oil mill effluent is illustrated in the following section.

\section{Emission calculations}

A scenario on emission reduction based on a methane recovery and utilisation project is illustrated (Fig. 1). The project activity involves the replacement of an existing open anaerobic lagoons palm oil mill effluent treatment system with an enclosed anaerobic granular-sludge-based treatment plant. The biogas generated will be captured in the anaerobic enclosed tanks through a 3-phase separator as shown in Fig. 2. The captured biogas will be utilised to replace the fossil fuels used in the steam boilers and/or thermal heaters. Excess biogas will be flared. The existing treatment system is based on the most common treatment method adopted by the industry in Malaysia, which involves the application of deep open anaerobic lagoons followed by facultative/aerobic shallow ponds where methane generated is released to the atmosphere. The effluent from the existing anaerobic lagoons is treated by the aerobic ponds to further reduce the organic pollutants to an acceptable concentration level before discharging to the waterways. The project activity contributes to greenhouse gas emission reduction by recovering the methane gas generated from the anaerobic granulation process, as well as utilising the biogas generated to displace fossil fuels for boilers and/or thermal heaters.

Palm oil mill effluent is ranked among the strongest industrial wastewater in terms of organic matter contents. The 


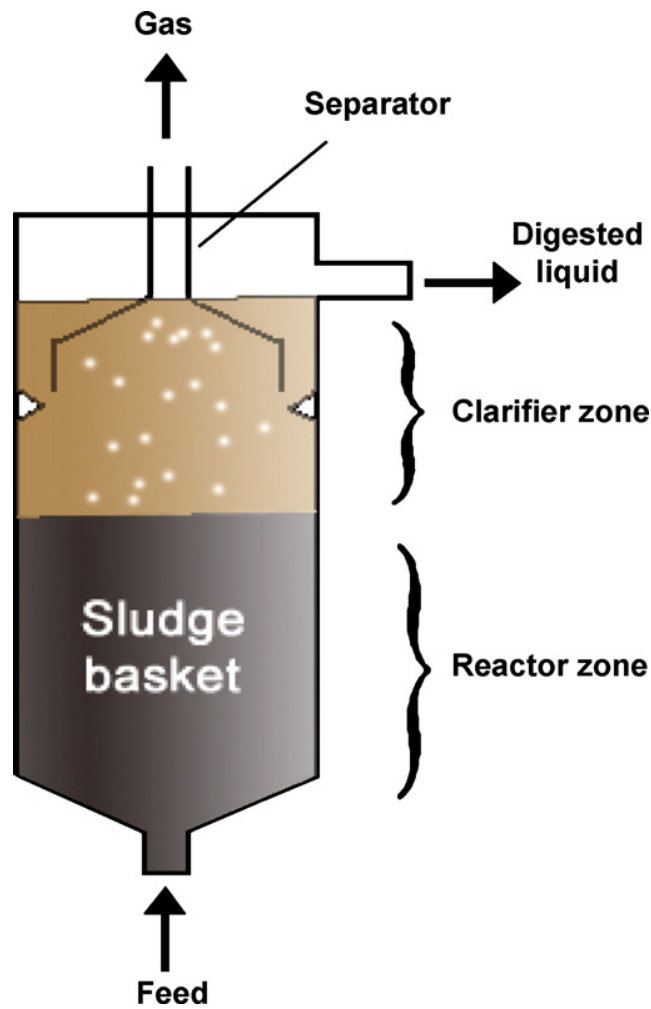

Fig. 2. Conceptual drawing of the anaerobic granular-sludge-based reactor incorporating 3-phase separator.

mill effluent is characterised by very high organic matter contents derived from the organic fractions of the palm oil production process with an average biological oxygen demand (BOD) and chemical oxygen demand (COD) level of 25,000 and $55,000 \mathrm{mg} / \mathrm{L}$, respectively. Most palm oil mills generate large volumes of mill effluent.

As a basis of the calculations, a total of $400 \mathrm{~m}^{3}$ of palm oil mill effluent will be generated daily in the mill. The existing open lagoon anaerobic treatment will reduce the COD from about $55,000 \mathrm{mg} / \mathrm{L}$ to less than $10,000 \mathrm{mg} / \mathrm{L}$, and BOD from $25,000 \mathrm{mg} / \mathrm{L}$ to less than $500 \mathrm{mg} / \mathrm{L}$, with the production of biogas comprising mainly methane $\left(\mathrm{CH}_{4}\right)$ and carbon dioxide $\left(\mathrm{CO}_{2}\right)$ and traces of hydrogen sulphide $\left(\mathrm{H}_{2} \mathrm{~S}\right)$. The biogas is emitted to the atmosphere. The open shallow lagoon aerobic treatment in the second stage will further reduce the BOD to less than $100 \mathrm{mg} / \mathrm{L}$ to meet the regulatory requirements for watercourse discharge.

The COD removal efficiency of the anaerobic granularsludge-based treatment system is estimated to be $80-85 \%$. The methane generation rate is assumed to be $0.25 \mathrm{~kg} \mathrm{CH}_{4} / \mathrm{kg}$ COD converted, or a production rate of approximately $28 \mathrm{~m}^{3}$ biogas per $\mathrm{m}^{3}$ mill effluent is assumed. The closed-tank granularsludge-based treatment system allows for complete recovery of methane produced. The biogas generated shows typically the following composition and concentration ranges: $60-65 \% \mathrm{CH}_{4}$, 39-34\% $\mathrm{CO}_{2}, 1500-3000 \mathrm{ppm} \mathrm{H}_{2} \mathrm{~S}$, and the balance making up of water vapour.

The baseline emission calculations include the following aspects: baseline emissions, project emissions, leakage, and emission reductions for the project activity.

\subsection{Baseline emissions}

Baseline emissions are the $\mathrm{CH}_{4}$ emissions from open lagoon wastewater treatment systems, the $\mathrm{CO}_{2}$ emissions associated with grid electricity generation that is replaced by the project, and the $\mathrm{CO}_{2}$ emissions associated with fossil fuel combustion in the heating equipment.

\subsubsection{Baseline emissions from open lagoons}

The baseline emissions from the lagoons are estimated based on the chemical oxygen demand (COD) of the effluent that would enter the lagoon in the absence of the project activity, the maximum methane-producing capacity (MMC) and a methane conversion factor (MCF) that expresses what proportion of the effluent would be anaerobically degraded in the open lagoons.

The $\mathrm{CH}_{4}$ emissions from wastewater are calculated as follows:

$$
\begin{aligned}
& \mathrm{CH}_{4} \text { emissions }(\mathrm{kg} / \mathrm{y}) \\
& =\text { total } \mathrm{COD}_{\text {available }}(\mathrm{kg} \mathrm{COD} / \mathrm{y}) \\
& \quad \times \mathrm{MMC}(\mathrm{kg} \mathrm{CH} / \mathrm{kg} \mathrm{COD}) \times \mathrm{MCF}_{\text {baseline }}
\end{aligned}
$$

where, $\mathrm{COD}_{\text {available }}$, is the yearly $\mathrm{COD}$ available for conversion which is equal to the yearly COD entering the lagoons or the yearly COD of effluent entering the granular-sludge-based tanks in the case of project situation; MMC is the maximum methane-producing capacity; $\mathrm{MCF}_{\text {baseline }}$ is the methane conversion factor (fraction).

$\mathrm{COD}_{\text {available }}$ is to be directly measured by the project as the baseline activity level since the effluent that goes into the lagoon in the baseline situation is the same as the one that goes into the granular-sludge-based tank in the project situation. $\mathrm{COD}_{\text {available }}$ is calculated as the product of COD concentration $\left(\mathrm{kg} \mathrm{COD} / \mathrm{m}^{3}\right)$ in the wastewater input to the granular-sludgebased tanks and the flow rate. $\mathrm{MCF}_{\text {baseline }}$ is estimated as 0.45 considering the fraction of anaerobic degradation due to lagoon depth and the fraction of anaerobic degradation due to temperature.

Calculations of methane baseline emissions from open lagoons are as follows:

$$
\begin{aligned}
\text { Total } \mathrm{COD}_{\text {available }}= & 55 \mathrm{~kg} / \mathrm{m}^{3} \times 400 \mathrm{~m}^{3} / \mathrm{d} \times 300 \mathrm{~d} / \mathrm{y} \\
= & 6,600,600 \mathrm{~kg} / \mathrm{y} \text { (based on a typical } \\
& 300 \text { operation days per year) }
\end{aligned}
$$

$$
\begin{aligned}
& \mathrm{CH}_{4 \text { emissions }}(\mathrm{kg} / \mathrm{y}) \\
& =6,600,600 \mathrm{~kg} / \mathrm{y} \times 0.21 \times 0.45=623,700 \mathrm{~kg} / \mathrm{y}
\end{aligned}
$$

The default value for MMC given by Inter-governmental Panel on Climate Change (IPCC) for the maximum amount of $\mathrm{CH}_{4}$ that can be produced from a given quantity of wastewater is $0.25 \mathrm{~kg} \mathrm{CH}_{4} / \mathrm{kg}$ COD. Taking into account the uncertainty of this estimate, a conservatively value of $0.21 \mathrm{~kg} \mathrm{CH}_{4} / \mathrm{kg} \mathrm{COD}^{2}$ 
is used.

$$
\begin{aligned}
\text { Emission reduction } & =623,700 \times 21 \times 10^{-3} \\
& =13,083 \mathrm{tCO}_{2} \text { equivalent per year }
\end{aligned}
$$

The total baseline $\mathrm{CH}_{4}$ emission is translated into $\mathrm{CO}_{2}$ equivalent emissions by multiplying by its global warming potential (GWP) of 21 .

\subsubsection{Baseline emissions from grid electricity (or thermal)}

The baseline emissions from the grid electricity are the $\mathrm{CO}_{2}$ emissions associated with grid electricity generation that is replaced by the project, and the $\mathrm{CO}_{2}$ emissions associated with fossil fuel combustion in the heating equipment. The emissions are estimated based on the quantity of thermal energy that would be consumed in a year at the project site in the absence of the project activity (MJ) using fossil fuel, and the $\mathrm{CO}_{2}$ emissions intensity for thermal energy generation.

The baseline emissions from the grid electricity are calculated as follows:

$\mathrm{BE}_{\text {elec } / \text { heat }}=\mathrm{HG}_{\mathrm{Bl}} \times \mathrm{CEF}_{\mathrm{Bl} \text {,therm }}$

where $\mathrm{HG}_{\mathrm{B} 1}$ is the quantity of thermal energy that would be consumed in a year at the project site in the absence of the project activity (MJ) using fossil fuel; $\mathrm{CEF}_{\mathrm{Bl} \text {,therm }}$ is the $\mathrm{CO}_{2}$ emission intensity for thermal energy generation $\left(\mathrm{tCO}_{2} / \mathrm{MJ}\right)$, assumed to be $77.37 \mathrm{tCO}_{2} / \mathrm{TJ}_{\text {oil }}$ based on IPCC Guidelines for National Greenhouse Gas Inventories, Reference Manual, 1996.

Assuming

(i) negligible amount of electricity that would be consumed at the project site in the absence of the project activity and

(ii) export of electricity to the grid from electricity generation from methane captured during project activity is not intended.

Calculations of electricity baseline emissions are as follows:

Mass of $\mathrm{CH}_{4}$ captured during project activity

$$
\begin{aligned}
= & (55-10) \mathrm{kg} / \mathrm{m}^{3} \times 400 \mathrm{~m}^{3} / \mathrm{d} \times 300 \mathrm{~d} / \mathrm{y} \\
& \times 0.21 \mathrm{~kg} \mathrm{CH} 4 / \mathrm{kg} \mathrm{COD} \text { converted } \\
= & 1,134,000 \mathrm{~kg} / \mathrm{y}
\end{aligned}
$$

Assuming a density of $\mathrm{CH}_{4}$ of $0.65 \mathrm{~kg} / \mathrm{m}^{3}$

$$
\text { Volume of } \begin{aligned}
\mathrm{CH}_{4} \text { captured } & =\frac{1,134,000 \mathrm{~kg} / \mathrm{y}}{0.65 \mathrm{~kg} / \mathrm{m}^{3}} \\
& =1,744,615 \mathrm{~m}^{3} / \mathrm{y}
\end{aligned}
$$

Assuming $85 \%$ utilisation for steam generation, thermal energy that can be generated by the methane recovered through the project activity is calculated as follows:

Volume of $\mathrm{CH}_{4}$ produced and utilised $/ \mathrm{y}=1,744,615 \mathrm{~m}^{3} / \mathrm{y}$ $\times 0.85$

Calorific value of $\mathrm{CH}_{4}=35.8 \mathrm{MJ} / \mathrm{m}^{3}$

Total thermal energy $=1,744,615 \times 0.85 \times 35.8=53.09$ $\mathrm{TJ} / \mathrm{y}$ (trillion joules per year)
As the methane recovered will displace the utilisation of the fossil fuel, the quantity of thermal energy for the generation of the same amount of steam using fossil fuel will be the same as that obtainable from methane recovered, assuming the same efficiency of the boiler for both types of fuel.

The thermal baseline emissions from the grid electricity are calculated as follows:

$$
\begin{aligned}
\mathrm{BE}_{\text {elec } / \text { heat }} & =\mathrm{HG}_{\mathrm{Bl}} \times \mathrm{CEF}_{\mathrm{Bl}, \text { therm }} \\
& =53.09 \mathrm{TJ} / \mathrm{y} \times 77.37 \mathrm{tCO}_{2} / \mathrm{TJ}_{\text {oil }} \\
& =4108 \mathrm{tCO}_{2} / \mathrm{y}
\end{aligned}
$$

Hence

$$
\begin{aligned}
\text { Total baseline emissions }= & \text { methane emissions } \\
& + \text { thermal emissions } \\
= & 13,083 \mathrm{tCO}_{2} / \mathrm{y}+4108 \mathrm{tCO}_{2} / \mathrm{y} \\
= & 17,191 \mathrm{tCO}_{2} / \mathrm{y}
\end{aligned}
$$

\subsection{Project emissions}

Project emissions mainly consist of methane emissions from the lagoons, physical leakage from the digester system, stack emissions from flaring and energy generating equipment, emissions related with the consumption of electricity in the digester auxiliary equipment, emissions from land application of sludge, and emissions from wastewater removed in the dewatering process. For this exercise, emissions from emission from heat use and electricity use due to the project activity, emissions from land application of sludge, and emissions from wastewater removed in the dewatering process are assumed to be negligible.

\subsubsection{Methane emissions from lagoons}

After the majority of the COD is treated by anaerobic degradation in the granular-sludge-based tanks, the effluent will pass through the aerobic ponds prior to discharge to the waterways. A significant majority of the COD load will have been reduced by anaerobic degradation and the ponds are expected to operate under largely aerobic conditions. The MCF value for fully aerobic systems is assumed to be negligible, and no methane would be produced.

However, due to the uncertainty regarding the exact extent of aerobic/anaerobic degradation after project implementation, the calculation of these $\mathrm{CH}_{4}$ emissions is conservatively carried out in the same way as for the baseline, using the same values for $\mathrm{MMC}$ and MCF.

$$
\begin{aligned}
& \mathrm{CH}_{4} \text { emissions from aerobic ponds }(\mathrm{kg} / \mathrm{y}) \\
& =\mathrm{COD}_{\text {granu_out }}(\mathrm{kg} \mathrm{COD} / \mathrm{y}) \times \mathrm{MMC}\left(\mathrm{kg} \mathrm{CH}_{4} / \mathrm{kg} \mathrm{COD}\right) \\
& \quad \times \mathrm{MCF}_{\text {granu_out }}
\end{aligned}
$$

where $\mathrm{COD}_{\text {granu_out }}$ is $\mathrm{COD}$ of effluent from the granularsludge-based tanks entering lagoons; MMC is maximum 
methane-producing capacity $\left(0.21 \mathrm{~kg} \quad \mathrm{CH}_{4} / \mathrm{kg} \quad \mathrm{COD}\right)$; $\mathrm{MCF}_{\text {granu_out }}$ is methane conversion factor (fraction) estimated as described in the baseline section, equal to $\mathrm{MCF}_{\text {baseline }}(0.45)$.

$$
\begin{aligned}
\mathrm{COD}_{\text {granu_out }} & =10 \mathrm{~kg} / \mathrm{m}^{3} \times 400 \mathrm{~m}^{3} / \mathrm{d} \times 300 \mathrm{~d} / \mathrm{y} \\
= & 1,200,000 \mathrm{~kg} / \mathrm{y} \\
\mathrm{CH}_{4 \text { emissions }}= & 1,200,000 \mathrm{~kg} / \mathrm{y} \times 0.21 \times 0.45 \\
= & 113,400 \mathrm{~kg} / \mathrm{y}
\end{aligned}
$$

Emission reduction $=113,400 \times 21 \times 10^{-3}$

$$
=2381 \mathrm{tCO}_{2} / \mathrm{y}(\mathrm{GWP}=21)
$$

The total baseline $\mathrm{CH}_{4}$ emission are translated into $\mathrm{CO}_{2}$ equivalent emissions by multiplying by its GWP of 21.

\subsubsection{Physical leakage from granular-sludge-based tanks}

The emissions directly associated with the anaerobic tanks involve the physical leakage from the system is assumed to be negligible.

\subsubsection{Stack emissions from the flare or energy generation}

Methane may be released as a result of incomplete combustion either in the flaring option or in case of biogas used for electricity and/or heat production. These emissions are calculated as follows.

Assumptions made:

Methane production $=1,744,615 \mathrm{~m}^{3} / \mathrm{y}$ (calculated $)$

Fraction of biogas for flare $=15 \%$ (estimation)

Fraction of biogas for heating $=85 \%$ (estimation)

Fraction $\mathrm{CH}_{4}$ released due to incomplete flare $=0.50$

Density of $\mathrm{CH}_{4}=0.65 \mathrm{~kg} / \mathrm{m}^{3}$

$\mathrm{CH}_{4}$ emission due to incomplete combustion during flaring

$$
\begin{aligned}
& =1,744,615 \times 15 \% \times 0.65 \mathrm{~kg} / \mathrm{m}^{3} \times 0.50 \\
& =85,050 \mathrm{~kg} / \mathrm{y}
\end{aligned}
$$

Assuming combustion of biogas in boiler, similar as enclosed flare, at $99 \%$ efficiency, $\mathrm{CH}_{4}$ emission due to incomplete combustion during thermal energy generation

$$
\begin{aligned}
& =1,744,615 \times 85 \% \times 0.65 \mathrm{~kg} / \mathrm{m}^{3} \times 0.01 \\
& =9639 \mathrm{~kg} / \mathrm{y}
\end{aligned}
$$

Total emission due to incomplete flare and incomplete heat generation

$$
\begin{aligned}
& =85,050+9639 \\
& =94,689 \mathrm{kgCH}_{4} / \mathrm{y} \\
& =1988 \mathrm{tCO}_{2} \text { emission } / \mathrm{y}(\mathrm{GWP}=21)
\end{aligned}
$$

Combining the above three emissions:

Total project emissions $=2381+0+1988=4369 \mathrm{tCO}_{2} / \mathrm{y}$.

\subsection{Total emission reductions}

Total emission reductions

$=$ baseline emissions from open lagoons

- project emissions

$$
\begin{aligned}
& =17,191-4369 \\
& =12,822 \mathrm{tCO}_{2} / \mathrm{y}
\end{aligned}
$$

Expected emission reductions from the first 5-year crediting period from 2008 to 2012

$$
\begin{aligned}
& =12,822 \times 5 \\
& =64,110 \mathrm{tCO}_{2}
\end{aligned}
$$

Assuming a carbon trading price of US\$ 5 per tonne carbon dioxide, the total CERs claimed arising from the CDM project $=64,110 \times 5=$ US $\$ 320,550$.

It is estimated that the proposed project activity requires an investment of about US\$ 1.5 millions for design, construction, equipment, installation and commissioning, with a reasonably attractive investment return period of less than 5 years. As application of the granular-sludge-based anaerobic technology is relatively new in most developing countries, there is no known financial scheme from bank or financial institution to support such an activity. Preliminary financial analysis has concluded that the proposed project activity is economically or financially less attractive than other alternatives without the revenue from the sale of the CERs. The proposed CDM project activity on avoided methane emissions from organic wastewater treatment contributes to the reductions of anthropogenic emissions by sources below those that would have occurred in the absence of the CDM project. In addition, a financially more viable alternative to project activity is unlikely lead to any emission reduction.

\section{Future trend}

Global carbon emission trading has been steadily increasing in recent years. According to the World Bank's Carbon Finance Unit, 374 million metric tonnes of carbon dioxide equivalent were exchanged through projects in 2005, a $240 \%$ increase relative to 2004 at 110 million metric tonnes of carbon dioxide, which was itself a $41 \%$ increase relative to 2003 (78 million metric tonnes of carbon dioxide). A sharp rise in the number of transactions in the emissions trading market brought the value of trades to about $\$ 64$ billion last year, says the World Bank in an annual review in 2008 (World Bank, 2008). A study by New Carbon Finance (2008) revealed that the United States will be home to a US\$ 1 trillion carbon emission market by 2020 if federal and state policymakers continue on their current path towards a comprehensive "cap-and-trade" program that is confined to domestic trading only.

The current median price in early 2008 for US carbon credits is around 6 US\$ per metric tonne of carbon dioxide. Carbonpositive (2008) predicts a U.S. carbon price of US\$ 35-40 per tonne by 2015. In May 2008, CERs for delivery in December 2008 hovered around $€ 16$ (US\$ 25) on the Nord 
Pool exchange, and €25 (US\$ 39) on EU Emission Trading Scheme market in Europe (Carbonpositive, 2008).

New insights into the anaerobic degradation of very different categories of compounds, and into process and reactor technology will lead to very promising new generations of anaerobic treatment systems. By integrating the anaerobic process with other biological methods such as aerobic lagoons and with physical-chemical methods (for example MBR), a complete treatment of the wastewater can be accomplished at very low costs, while at the same time valuable resources can be recovered for reuse.

\section{Conclusions}

Greater efforts are now needed for broader applications of anaerobic granulation system for ridding the environment of unwanted organic materials by converting them into a renewable energy source-methane. Anaerobic granular systems can be designed in wastewater treatment to maximize methane yield. The methane can be effectively captured rendering great potential for CERs under the CDM initiatives. Looking at the prospects of carbon trading, it may not be an unreasonable expectation that, in the future, wastewater treatment will experience a global shift towards employment of highly efficient granular-sludge-based anaerobic processes maximising energy production and greenhouse gas emission reductions.

\section{References}

Chang, L. H. and C. M. J. Chang, "Continuous Hot Pressurized Fluids Extraction of Isoflavones and Soyasaponins from Defatted Soybean Flakes," J. Chin. Inst. Chem. Engrs., 38, 313 (2007).

Chen, C. R., Y. N. Lee, C. M. J. Chang, M. R. Lee, and I. C. Wei, "HotPressurized Fluid Extraction of Flavonoids and Phenolic Acids from Brazilian Propolis and Their Cytotoxic Assay In Vitro," J. Chin. Inst. Chem. Engrs., 38, 191 (2007).

Chiou, C. S., Y. H. Chen, C. Y. Chang, J. L. Shie, C. C. Liu, and C. T. Chang, "Photochemical Oxidation of Polyethylene Glycol in Aqueous Solution by UV/ $\mathrm{H}_{2} \mathrm{O}_{2}$ with Steel Waste," J. Chin. Inst. Chem. Engrs., 37, 321 (2006).

Ghoneim, S. A. and N. A. K. Aboul-Gheit, "Effect of Steam Treatment on the Activities of $\mathrm{Pt} / \mathrm{NH}_{4}-\mathrm{MOR}$. Catalysts for $n$-Pentane Hydroisomerization and Hydrocracking," J. Chin. Inst. Chem. Engrs., 38, 251 (2007).

Hacifazlioglu, H. and H. Sutcu, "Optimization of Some Parameters in Column Flotation and a Comparison of Conventional Cell and Column Cell in Terms of Flotation Performance," J. Chin. Inst. Chem. Engrs., 38, 287 (2007).

He, P. J., F. Lu, L. M. Shao, X. J. Pan, and D. J. Lee, "Kinetics of Enzymatic Hydrolysis of Polysaccharide-Rich Particulates," J. Chin. Inst. Chem. Engrs., 38, 21 (2007).

Hung, C. C. Y. and M. H. Rei, "Constant Concentration Method of Measuring Hydrogen Permeation from a Hydrogen Mixture with Pd Membrane," $J$. Chin. Inst. Chem. Engrs., 38, 341 (2007).

Kasim, N. S., H. Chen, and Y. H. Ju, "Recovery of Gamma-Oryzanol from Biodiesel Residue," J. Chin. Inst. Chem. Engrs., 38, 229 (2007).

Kim, T. H., H. Rupani, S. Pallavkar, J. Hopper, T. Ho, and C. J. Lin, "Destruction of Toxic Volatile Organic Compounds (VOCs) in a Microwave-Assisted Catalyst Bed,” J. Chin. Inst. Chem. Engrs., 37, 519 (2006).

Li, P. S. and H. S. Teng, "Electrodeposited Amorphous Iron(III) Oxides as Anodes for Photoelectrolysis of Water," J. Chin. Inst. Chem. Engrs., 38, 267 (2007).

Lin, R. B. and S. M. Shih, "Cyclic Voltammetric Measurement of Catalyst Surface Area for Pt-Black/Nafion Electrodes," J. Chin. Inst. Chem. Engrs., 37, 311 (2006).
Lin, R. B. and S. M. Shih, "Kinetics of Hydrogen Oxidation Reaction on Nafion-Coated Pt/C Electrodes under High Overpotentials," J. Chin. Inst. Chem. Engrs., 38, 365 (2007).

Ma, Y., X. F. Peng, and D. J. Lee, "Stereological Estimation of Structural Change in Floc Matrix Following Weak Ultrasonication," J. Chin. Inst. Chem. Engrs., 38, 275 (2007).

Matsuda, K., K. Huang, M. Nakaiwa, T. Ohmori, A. Endo, T. Yamamoto, S. Kataoka, K. Iwakabe, T. Nakanishi, K. Kataoka, and T. Takamatsu, "Simulation of Ternary Distillation in a Heat Integrated Distillation Column (HIDiC) with a Rate-based Model," J. Chin. Inst. Chem. Engrs., 37, 467 (2006).

Monyanon, S., S. Pongstabodee, and A. Luengnaruemitchai, "Preferential Oxidation of Carbon Monoxide over Pt, Au Monometallic Catalyst, and PtAu Bimetallic Catalyst Supported on Ceria in Hydrogen-rich Reformate," J. Chin. Inst. Chem. Engrs., 38, 435 (2007).

New Carbon Finance, http://www.carbonpositive.net/viewarticle.aspx?articleID =98. http://www.newcarbonfinance.com, May (2008).

Otawara, K. and T. Kitamura, "Comparison of a Belt-filter and Centrifuge in the Crystal Purification Process with CDC (Cooling Disc Crystallizer) and KCP (Kureha Crystal Purifier)," J. Chin. Inst. Chem. Engrs., 37, 509 (2006).

Sutcu, H., "Pyrolysis by Thermogravimetric Analysis of Blends of Peat with Coals of Different Characteristics and Biomass," J. Chin. Inst. Chem. Engrs., 38, 245 (2007).

Wang, H. and H. Z. Chen, "A Novel Method of Utilizing the Biomass Resource: Rapid Liquefaction of Wheat Straw and Preparation of Biodegradable Polyurethane Foam (PUF)," J. Chin. Inst. Chem. Engrs., 38, 95 (2007).

Wang, M. L. and B. L. Liu, "Synthesis of 2-Mercaptobenzimidazole from the Reaction of $o$-Phenylene Diamine and Carbon Disulfide in the Presence of Potassium Hydroxide," J. Chin. Inst. Chem. Engrs., 38, 161 (2007a).

Wang, M. L. and B. L. Liu, "Homogeneous Catalyzed Reaction of Carbon Disulfide and $o$-Phenylene Diamine by Tetrabutylammonium Hydroxide in the Presence of Potassium Hydroxide," J. Chin. Inst. Chem. Engrs., 38, 85 (2007b).

Wang, M. L., B. L. Liu, and S. J. Lin, "Synthesis of an Active Quaternary Phosphonium Salt and Its Application to the Wittig Reaction: Kinetic Study," J. Chin. Inst. Chem. Engrs., 38, 451 (2007).

Wei, T. Y., S. Y. Lu, and Y. C. Chang, "Rich Photoluminescence Emission of $\mathrm{SnO}_{2}-\mathrm{SiO}_{2}$ Composite Aerogels Prepared with a Co-Fed Precursor Sol-Gel Process," J. Chin. Inst. Chem. Engrs., 38, 477 (2007).

World Bank, State and Trends of the Carbon Market 2008, Carbon Finance Unit, World Bank Institute, Washington, DC, http://carbonfinance.org/Router. cfm?Page $=$ DocLib\&CatalogID $=40347$.

Wu, H. M. and J. H. You, "Destruction of Methyl Ethyl Ketone Vapor by Ozone on Activated Carbon," J. Chin. Inst. Chem. Engrs., 38, 117 (2007).

Wu, K. J., J. S. Chang, and C. F. Chang, "Biohydrogen Production Using Suspended and Immobilized Mixed Microflora," J. Chin. Inst. Chem. Engrs., 37, 545 (2006).

Yao, J. Y., S. Y. Lin, and I. L. Chien, "Operation and Control of Batch Extractive Distillation for the Separation of Mixtures with MinimumBoiling Azeotrope," J. Chin. Inst. Chem. Engrs., 38, 371 (2007).

Yeh, H. M., "Recoveries of Deuterium from the Separation of Water-Isotope Mixture in Batch-Type Thermal Diffusion Columns under Unsteady-State Operation," J. Chin. Inst. Chem. Engrs., 38, 495 (2007).

Yu, C. Y., W. S. Liang, I. Kuan, C. H. Wei, and W. G. Gu, "Fabrication and Characterization of a Flow-through PCR Device with Integrated Chromium Resistive Heaters," J. Chin. Inst. Chem. Engrs., 38, 333 (2007a).

Yu, M. C., R. C. Wang, C. Y. Wang, K. J. Duan, and D. C. Sheu, "Enhanced Production of L(+)-Lactic Acid by Floc-Form Culture of Rhizopus Oryzae," J. Chin. Inst. Chem. Engrs., 38, 223 (2007b).

Yu, W. Y., W. S. Lee, C. P. Yang, and B. Z. Wan, "Low-Temperature Preferential Oxidation of CO in a Hydrogen Rich Stream (PROX) over $\mathrm{Au} / \mathrm{TiO}_{2}$ : Thermodynamic Study and Effect of Gold-colloid pH Adjustment Time on Catalytic Activity," J. Chin. Inst. Chem. Engrs., 38, 151 (2007c). 